\title{
Long-term Sub-zero Treatment of P/M Vanadis 6 Ledeburitic Tool Steel - a Preliminary Study
}

Peter Jurči ${ }^{1}$, Martin Kusý ${ }^{1}$, Jana Ptačinová ${ }^{1}$, Vladimír Kuracina ${ }^{1}$, Petra Priknerová ${ }^{2}$

${ }^{1}$ Faculty of Material Sciences and Technology in Trnava, Paulínská 16, 91724 Trnava, Slovakia, p.jurci@seznam.cz (corresponding author)

${ }^{2}$ Prikner - tepelné zpracování kovů, Martínkovice 279, 550 01, Czech Republic, Priknerová Petra (p.priknerova@prikner.cz)

The microstructure, the phase constitution and the tempering charts of $\mathrm{Cr}$-V ledeburitic steel Vanadis 6 subjected to sub-zero treatment with various soaking times in liquid nitrogen have been investigated. The microstructures have been characterized using the light microscopy, scanning electron microscopy and X-ray diffraction. The hardness has been evaluated by Vickers method. The matrix is martensitic with certain amount of retained austenite, irrespectively to the time of sub-zero treatment. The amount of retained austenite, however, decreases up to the soaking time of $17 \mathrm{~h}$ and then remains almost constant. The microstructure of sub-zero treated steel contains enhanced portion of small globular carbides, as compared to conventionally heat treated material. These particles have a size of around $100 \mathrm{~nm}$ in most cases. The as-quenched hardness manifests a moderate increase due to the sub-zero treatment. The hardness decreases during subsequent tempering and this decrease is more pronounced in sub-zero treated samples.

Keywords: $\mathrm{Cr}-\mathrm{V}$ ledeburitic steel, sub-zero treatment, retained austenite and martensite, carbides, hardness

\section{Acknowledgement}

This paper is a result of the project implementation: $C E$ for development and application of advanced diagnostic methods in processing of metallic and non-metallic materials, ITMS:26220120048, supported by the Research \& Development Operational Programme funded by the ERDF. Moreover, the paper is a result of preliminary experiments of the project VEGA 1/0735/14.

\section{References}

[1] DAS, D., RAY, K.K., DUTTA, A.K. (2009). Influence of temperature of sub-zero treatments on the wear behaviour of die steel. Wear, Vol. 267, pp. $1361-1370$.

[2] DAS, D., DUTTA, A.K., RAY, K.K. (2009). Influence of varied cryotreatment on the wear behaviour of AISI D2 steel. Wear, Vol. 266, pp. $297-309$.

[3] DAS, D., DUTTA, A.K., RAY, K.K. (2010). Sub-zero treatments of AISI D2 steel: Part II. Wear behaviour. Mater. Sci. Engng., Vol. A527, pp. $2194-2206$.

[4] DAS, D., DUTTA, A.K., RAY, K.K. (2009). Optimization of the duration of cryogenic processing to maximize wear resistance of AISI D2 steel. Cryogenics, Vol. 49, pp. 176 - 184.

[5] STRATTON, P.F. (2007). Optimising nano-carbide precipitation in tool steels. Mater. Sci. Engng., Vol. A449451, pp. $809-812$

[6] MOHAN LAL, D., RENGANARAYANAN, S., KALANIHIDI, A. (2001). Cryogenic treatment to augment wear resistance of tool and die steels. Cryogenics, Vol. 41, pp. $149-155$.

[7] AMINI, K., AKHBARIZADEH, A., JAVADPOUR, S. (2013). Investigating the effect of the quench environment on the final microstructure and wear behaviour of 1.2080 tool steel after deep cryogenic heat treatment. Mater. Design, Vol. 45, pp. $316-322$.

[8] AKHBARIZADEH, A., AMINI, K., JAVADPOUR, S. (2012). Effects of applying an external magnetic field during the deep cryogenic heat treatment on the corrosion resistance and wear behaviour of 1.2080 tool steel. Mater. Design, Vol. 41, pp. $114-123$.

[9] AMINI, K., AKHBARIZADEH, A., JAVADPOUR, S. (2012). Investigating the effect of holding duration on the microstructure of 1.2080 tool steel during the deep cryogenic treatment. Vacuum, Vol. 86, pp. $1534-1540$.

[10] DAS, D., SARKAR, R., DUTTA, A.K., RAY, K.K. (2010). Influence of sub-zero treatments on fracture toughness of AISI D2 steel. Mater. Sci. Engng., Vol. A528, pp. $589-603$. 
[11] JURČI, P., ŠUŠTARŠIČ, B., LESKOVŠEK, V. (2010). Fracture Characteristics of the Cr-V Ledeburitic Steel Vanadis 6. Materiali in Tehnologije/Materials and Technology, Vol. 44, pp. 79 - 86.

[12] BERNS, H. (1974). Restaustenit in ledeburitischen Chromstählen und seine Umwandlung durch Kaltumformen, Tiefkühlen und Anlassen. HTM, Vol. 29, pp. 236 - 247.

[13] PELliZZARI, M., MOLINARI, A. (2002). Deep Cryogenic Treatment of Cold Work Tool Steel. In: Proc. of the 6th Int. Tooling Conf., (J. Bergstrom, G. Fredriksson, M. Johansson, O. Kotik, F. Thuvander (Ed.)), pp. 547 - 558 , Karlstad University, Karlstad, Sweden.

[14] JURČI, P., SOBOTOVÁ, J., SALABOVÁ, P., PRIKNER, O., ŠUŠTARŠIČ, B., JENKO, D. (2013). Subzero treatment of P/M Vanadis 6 ledeburitic tool steel. Int. Heat Treatment and Surf. Engng., Vol. 7, pp. 125 - 128.

[15] TYSHCHENKO, A.I. THEISEN, W., OPPENKOWSKI, A., SIEBERT, S., RAZUMOV, O.N., SKOBLIK, A.P., SIROSH, V.A., PETROV, J.N., GAVRILJUK, V.G. (2010). Low-temperature martensitic transformation and deep cryogenic treatment of a tool steel. Mater. Sci. Engng., Vol. A527, pp. $7027-7039$.

[16] COLLINS, D.N., DORMER, J. (1997). Deep Cryogenic Treatment of a D2 Cold-Work Tool Steel. Heat Treatment of Metals, Vol. 24, pp. $71-74$.

[17] GAVriluUK, V.G., THEISEN, W., SIROSH, V.V., POLSHIN, E.V., KORTMANN, A., MOGILNY, G.S., PETROV, J.N., TARUSIN, Y.V. (2013). Low-temperature martensitic transformation in tool steels in relation to their deep cryogenic treatment. Acta Mater., Vol. 61, pp. 1705 - 1715.

[18] DAS, D., RAY, K.K. (2012). Structure-property correlation of cub-zero treated AISI D2 steel. Mater. Sci. Engng., Vol. A541, pp. $45-60$.

[19] DAS, D., DUTTA, A.K., RAY, K.K. (2010). Sub-zero treatments of AISI D2 steel: Part II. Wear behaviour. Mater. Sci. Engng., Vol. A527, pp. $2182-2193$.

[20] BÍLEK, P., SOBOTOVÁ, J., JURČI, P. (2011). Evaluation of the Microstructural Changes in Cr-V Ledeburitic Tool Steel Depending on the Austenitization Temperature. Materiali in Tehnologije/Materials and Technology, Vol. 44, pp. $489-493$.

[21] ASTM E975-13: Standard Practice for X-Ray Determination of Retained Austenite in Steel with Near Random Crystallographic Orientation, ASTM Book of Standards, vol. 3.01, West Conshohocken, PA, USA, 2004.

[22] SURBERG, C.H., STRATTON, P., LINGENHOELE, K. (2008). The effect of some heat treatment parameters on the dimensional stability of AISI D2. Cryogenics, Vol. 48, pp. $42-47$.

[23] STOJKO, A. (2006). The Effect of Cryogenic Treatment on Structural and Phase Transformations in Iron-Carbon Martensite. PhD Thesis, Technical University of Denmark, Lyngby, Denmark.

[24] DAS, D., DUTTA, A.K., TOPPO, V., RAY, K.K.. (2007). Effect of Deep Cryogenic Treatment on the Carbide Precipitation and Tribological Behavior of D2 Steel. Mater. Manuf. Process, Vol. 22, pp. $474-480$.

[25] COLLINS, D.N. (1996). Deep cryogenic treatment of tool steels - a review. Heat treatment of metals, Vol. 2, pp. 40-42.

[26] MENG, F., TAGASHIRA, K., AZUMA, R., SOHMA, H. (1994). Role of Eta-carbide Precipitation's in the Wear Resistance Improvements of Fe-12Cr-Mo-V-1.4C Tool Steel by Cryogenic Treatment. ISIJ Int., Vol. 34, pp. 205 -210 .

[27] AKHBARIZADEH, A., SHAFYEI, A., GOLOZAR, M.A. (2009). Effects of cryogenic treatment on wear behaviour of D6 tool steel. Mater. Des., Vol. 30, pp. 3259 - 3264.

[28] JURČI, P., KUSÝ, M., DOMÁNKOVÁ, M., ČAPLOVIČ, L., SOBOTOVÁ, J., SALABOVÁ, P., PRIKNER, O., JENKO, D. (2013). Tempering response of sub-zero procesed Cr-V ledeburitic steel Vanadis 6. In: Proc. of the 22nd Int. Conf. on Metallurgy and Materials (METAL) (TANGER s.r.o. (Ed.)), pp. 651 - 656, Tanger s.r.o., Brno, Czech Republic. 